\title{
DISTRIBUTION OF AUTHIGENIC AND ALLOGENIC FRACTIONS IN RECENT LAKE SEDIMENT: ISOTOPIC AND CHEMICAL COMPOSITIONS
}

\author{
PORAZDELITEV AVTIGENE IN ALOGENE FRAKCIJE \\ V RECENTNIH JEZERSKIH SEDIMENTIH: IZOTOPSKA IN \\ KEMIJSKA SESTAVA
}

\author{
Jadranka BAREŠIĆ ${ }^{1}$, Nada HORVATINČIĆ ${ }^{1^{*}}$, Polona VREČÁ ${ }^{2}$ \& Andreja SIRONIĆ1
}

\begin{abstract}
UDC 552.5:544.02(497.5)

Jadranka Barešić, Nada Horvatinčić, Polona Vreča \& Andreja Sironić: Distribution of authigenic and allogenic fractions in recent lake sediment: Isotopic and chemical compositions

Recent sediments in Lake Kozjak, in the Plitvice Lakes National Park, Croatia, were used to study the impact of the material delivered to the lake sediment via Rječica Brook. Sediment cores, top $40 \mathrm{~cm}$, were taken near the mouth of the Rječica Brook at three locations in the lake at different distances from the shore, water depth 2-9 $\mathrm{m}$ and analyzed using different isotopic and chemical methods. Sediment depth profiles of the following parameters were obtained: organic and carbonate fraction, $\mathrm{C} / \mathrm{N}$ analyses of organic fraction, ${ }^{14} \mathrm{C}$ activity $\left(\mathrm{a}^{14} \mathrm{C}\right)$ and $\delta^{13} \mathrm{C}$ values of carbonate $\left(\delta^{13} \mathrm{C}_{\text {carb }}\right)$ and organic fraction $\left(\delta^{13} \mathrm{C}_{\text {org }}\right)$ and $\delta^{15} \mathrm{~N}$ of total nitrogen. The results were compared with sediment core collected in the middle of Lake Kozjak, water depth $21 \mathrm{~m}$. Distribution of organic matter, $\mathrm{C} / \mathrm{N}$ values, $\delta^{13} \mathrm{C}_{\text {org }}$ and $\delta^{13} \mathrm{C}_{\text {carb }}$ in sediment profiles showed strong influence of terrestrial organic and carbonate fraction run-off via Rječica Brook which decreased rapidly in the direction of the open lake. The sedimentation rate as well as the ratio of allogenic and authigenic fraction in sediments was estimated. Lower $\delta^{13} \mathrm{C}_{\text {org }}$ values in surface sediments might be a consequence of the increase in algal productivity but might also be a contribution of fossil fuel combustion. The anthropogenicaly induced ${ }^{14} \mathrm{C}$ in the atmosphere in 1963/64 is visible though shadowed in sediments.

Keywords: Lake sediment, Authigenic and allogenic fraction, Radiocarbon, Stable isotopes of C and N, Organic matter, C and $\mathrm{N}$ analyses.
\end{abstract}

\begin{abstract}
Izvleček
UDK 552.5:544.02(497.5)

Jadranka Barešić, Nada Horvatinčić, Polona Vreča \& Andreja Sironić: Porazdelitev avtigene in alogene frakcije $v$ recentnih jezerskih sedimentih: izotopska in kemijska sestava

V jezeru Kozjak na območju Nacionalnega parka Plitvička jezera smo $\mathrm{v}$ recentnih sedimentih raziskali vpliv snovi, ki dotekajo s potokom Rječica. Jedra sedimenta (zgornjih $40 \mathrm{~cm}$ ) smo odvzeli na treh lokacijah v priobalnem območju jezera Kozjak na globinah od 2-9 m. V jedrih sedimenta smo določili delež organske in karbonatne frakcije, $\mathrm{C} / \mathrm{N}$ razmerje $\mathrm{v}$ organski frakciji, aktivnost ${ }^{14} \mathrm{C}\left(\mathrm{a}^{14} \mathrm{C}\right), \delta^{13} \mathrm{C}$ v karbonatni $\left(\delta^{13} \mathrm{C}_{\text {carb }}\right)$ in organski $\left(\delta^{13} \mathrm{C}_{\text {org }}\right)$ frakciji ter $\delta^{15} \mathrm{~N}$ celotnega dušika. Rezultate naših analiz smo primerjali $z$ rezultati iz osrednjega dela jezera, kjer je bil sediment odvzet na globini $21 \mathrm{~m}$. Določili smo hitrost sedimentacije ter delež alogene in avtigene frakcije $\mathrm{v}$ sedimentih. Porazdelitve organske snovi, $\mathrm{C} / \mathrm{N}$ vrednosti, $\delta^{13} \mathrm{C}_{\text {org }}$ in $\delta^{13} \mathrm{C}_{\text {carb }}$ v sedimentnih profilih kažejo na velik vpliv organske in karbonatne frakcije, ki sta s potokom Riječica prineseni s kopna. Vpliv potoka se $\mathrm{z}$ oddaljenostjo od sotočja $\mathrm{z}$ jezerom hitro zmanjšuje. Nižje vrednosti $\delta^{13} \mathrm{C}_{\text {org }} \mathrm{v}$ površinskih sedimentih nakazujejo na vpliv rastoče primarne produkcije in vpliv izgorevanja fosilnih goriv. Ugotovili smo tudi vpliv atmosferskega antropogenega ${ }^{14} \mathrm{C}$ iz let 1963/64.

Ključne besede: jezerski sedimenti, avtigena in alogena frakcija, radioaktivni ogljik, stabilni izotopi $\mathrm{C}$ in $\mathrm{N}$, organska snov, $\mathrm{C}$ in $\mathrm{N}$ analize.
\end{abstract}

\footnotetext{
${ }^{1}$ Rudjer Bošković Institute, Bijenička 54, 10000 Zagreb, Croatia, e-mails: jadranka.baresic@irb.hr, nada.horvatincic@irb.hr, andreja.sironic@irb.hr

${ }^{2}$ Jožef Stefan Institute, Jamova 39, 1000 Ljubljana, Slovenia, e-mail: polona.vreca@ijs.si
}

Received/Prejeto: 6.9.2010 


\section{INTRODUCTION}

Lake sediments may provide a continuous, high-resolution record of environmental changes within the lake ecosystem and regional catchment. Mineral, organic, and isotopic composition of lacustrine sediments can provide important information of palaeoenvironmental changes, human-induced impact and also help in predicting future trends in environmental evolution following the global and local/regional influence of these changes (Talbot \& Laerdal 2000; Herczeg et al. 2001; Meyers 2003).

Lake sediments consist of organic and inorganic fraction that may be of varied origin. Organic matter in lake sediment has two sources: 1) It is produced in the lake by photosynthesis (autochthonous) and then buried as remains of organisms, 2) It is imported from the catchment via run-off rivers/streams (allochthonous), such as degraded remains of leaves, grass and soil organic matter (Meyers 2003). The inorganic fraction of the sediment consists of non-carbonate (mainly silicate) and carbonate minerals. The latter forms an important part of lake sediments in karst areas. The carbonate fraction can be authigenic precipitated from dissolved inorganic carbon (DIC) in water, or allogenic produced by eroded terrestrial material (Talbot 1990; Leng \& Marshall 2004).

Both, isotopic and geochemical composition of land-derived and aquatic organic matter and carbonate fractions of the lake sediments may help to identify their sources. For example, the $\mathrm{C}$ and $\mathrm{N}$ isotopic compositions of organic matter in sediments trace past changes in productivity in lacustrine environments (Brenner et al. 1999 ) as well as C/N ratios (Talbot \& Laerdal 2000; Herczeg et al. 2001). Likewise, $\delta^{13} \mathrm{C}$ and $\mathrm{C} / \mathrm{N}$ values can be used to resolve changes in the lacustrine and terrestrial environment that have influenced estuarine evolution (Meyers 2003; Lamb et al. 2007). Stable isotope ratios of ${ }^{13} \mathrm{C} /{ }^{12} \mathrm{C}$ and ${ }^{18} \mathrm{O} /{ }^{16} \mathrm{O}$ give additional information about environmental conditions, e.g. origin of carbon in sediment in both organic and carbonate fraction, bioactivity and productivity can be studied by $\delta^{13} \mathrm{C}$ and temperature variations by $\delta^{18} \mathrm{O}$ (Talbot 1990; Hodell \& Schelske 1998;
Lojen et al. 2004). Global contamination of atmospheric $\mathrm{CO}_{2}$ with ${ }^{14} \mathrm{C}$ produced by nuclear bomb tests in the 1960s (Levine \& Kromer 1997) can be seen in the ${ }^{14} \mathrm{C}$ record of recent sediments and can be used to estimate sedimentation rate (Srdoč et al. 1986b; McGeehin et al. 2004).

Previous study of recent lake sediments from several Plitvice Lakes, Croatia, showed varied mineral and chemical composition (Horvatinčić et al. 2006). Isotope compositions reflect different sedimentation rates as well as different response to the environmental changes in small and big lakes e.g. increase in primary productivity in small lakes in the last two decades (Horvatinčić et al. 2008).

In this paper, we present further investigation of recent sediments in a particular area of Lake Kozjak in the Plitvice Lakes system, close to mouth of Rječica Brook, where enhanced eutrophication was observed in the last decades. The aim of this study was to investigate the influence of terrestrial material transported by the Rječica Brook into the Kozjak Lake and its contribution to the eutrophication processes. Additionally, any change in the environment in the last 50 to 100 years, when tourist activity increased rapidly in this area, could be reflected in the sediment composition in which case it would give insight into the vulnerability of the lake system to the human influence.

Isotopic and chemical analysis of recent lake sediments from the Lake Kozjak were used to get more information on the composition of sediments, distribution of organic and carbonate fractions and to determine the origin of both organic and carbonate fractions in sediments. Additional information was given from water analysis at the area. The ratio of allogenic and authigenic fractions in the sediments regarding the distance from the Rječica Brook mouth was determined by different isotopic and chemical parameters which were compared and discussed.

\section{STUDY SITE}

Recent lake sediments were sampled from Lake Kozjak (altitude $540 \mathrm{~m}$ asl) which is part of the Plitvice Lakes system (Fig. 1). The Plitvice Lakes, situated in the Dinaric Karst in Central Croatia, consist of 16 lakes at different altitudes and are of different sizes. The lakes are interconnected by streams and waterfalls. The area is protected as a national park and the surrounding area is covered with woods, mostly deciduous trees. The lakes are characterized by intense calcium carbonate precipitation in the form of tufa forming tufa barriers and fine-grained sediments composed of authigenic calcite (Chafetz et al. 1994; Horvatinčić et al. 2006). Lake Kozjak is the largest lake in 

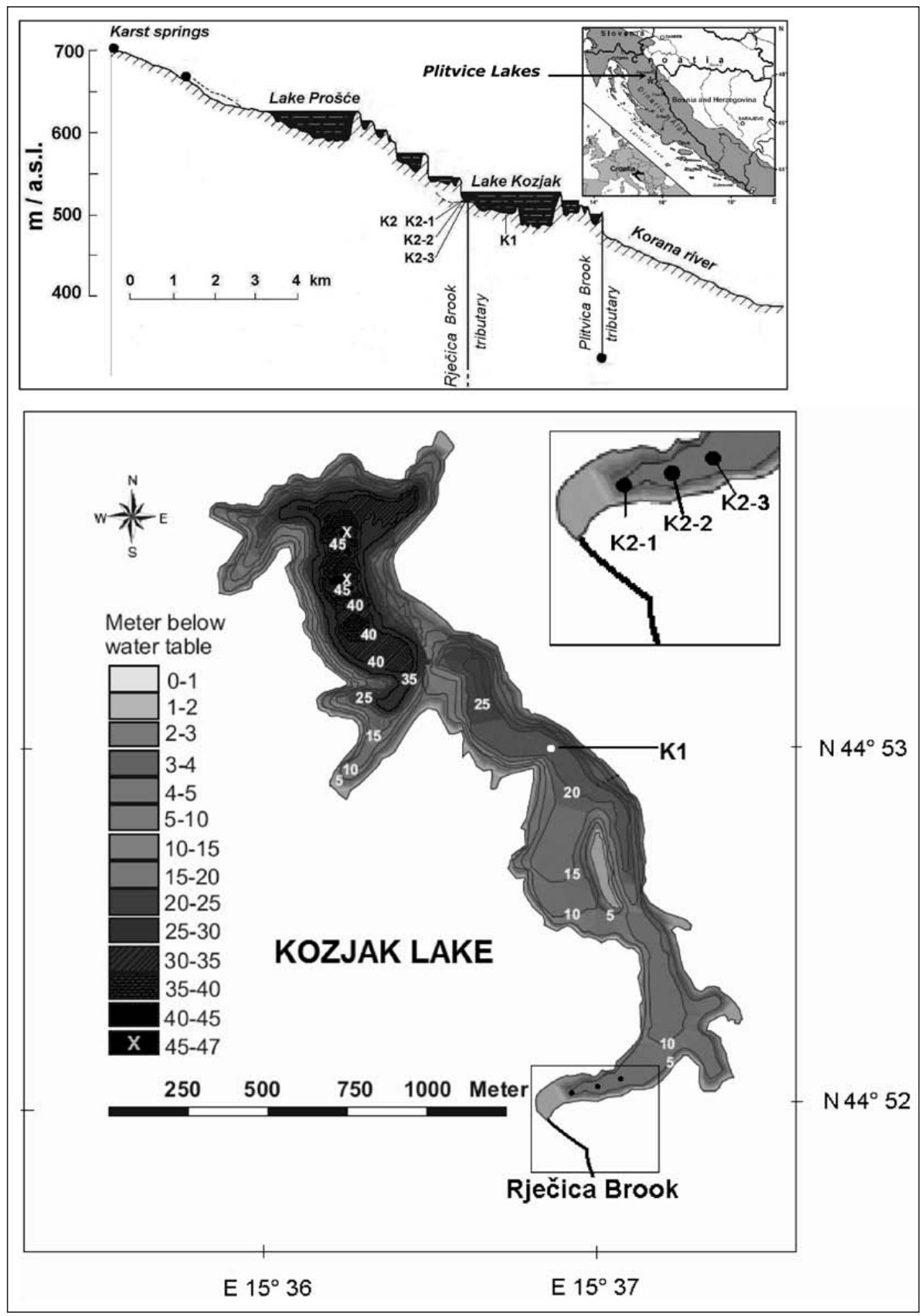

Fig. 1: Sampling sites for lake sediments in the Kozjak Lake presented in a cross section of the Plitvice Lakes system and in the map of Kozjak Lake. Sediment cores were taken in the lake center (K1) and in the area where the Rječica flows into the lake, at 3 different distances from the mouth of the stream. Kozjak Lake map after Petrik (1958) and Babinka (2007).

a submerged tufa barrier into two basins with maximum depth of $25 \mathrm{~m}$ (south basin) and $47 \mathrm{~m}$ (north basin). We investigated the inshore lake sediments close to the mouth of Rječica Brook, the most important tributary in the southern part of Lake Kozjak (Fig. 1, K2-1, K2-2 and K2-3 sites). This area is characterized by an extensive growth of macrophytes (reeds, grass, trees, etc.) inside the lake. The results of the sediment analyses from the Lake Kozjak close to the mouth of Rječica Brook (K2 sample sites) were compared with the composition of sediment collected in the centre of the Lake (K1), approximately $1000 \mathrm{~m}$ far from the mouth of Rječica Brook, where the influence

the system $\left(0.82 \mathrm{~km}^{2}\right)$ fed by water from the upper lakes and feeding the lower lakes (Fig. 1). The lake is divided by of Rječica Brook has not been expected to the sediment composition.

\section{MATERIALS AND METHODS}

\section{COLLECTION OF SAMPLES}

Lake sediments were collected in the area where the stream flows into the lake (Fig. 1) at three points: (1) near to the mouth of the Rječica Brook (core K2-1), (2) $\sim 50 \mathrm{~m}$ from the point 1 (core K2-2), and (3) $\sim 100 \mathrm{~m}$ away from the point 1 (core K2-3). Sediment core K2-1 was taken very close to the lake area covered by aquatic plants, mainly reeds (water depth $2 \mathrm{~m}$ ). Cores K2-2 and 
K2-3 were taken from the open lake at $4 \mathrm{~m}$ and $9 \mathrm{~m}$ water depth, respectively. Lake sediments, top $\sim 40 \mathrm{~cm}$, were collected by scuba divers using plastic corers of $50 \mathrm{~cm}$ length, and $10 \mathrm{~cm}$ diameter. In addition, we also present here the results of sediment core collected in the centre of Lake Kozjak, K1, at a water depth of $21 \mathrm{~m}$. The sediment cores were frozen and in the laboratory frozen sediments were cut into $1-2 \mathrm{~cm}$ thick layers and air dried $\left(60{ }^{\circ} \mathrm{C}\right)$ prior to analyses.

\section{METHODS}

In the lake sediments we analyzed both organic and carbonate fractions. In the organic fraction, we analyzed ${ }^{14} \mathrm{C}$ activity $\left(\mathrm{a}^{14} \mathrm{C}_{\text {org }}\right)$, isotopic composition of carbon $\left(\mathrm{\delta}^{13} \mathrm{C}_{\text {org }}\right)$ and $\mathrm{CHN}$ composition. In the carbonate fraction, we analyzed ${ }^{14} \mathrm{C}$ activity $\left(\mathrm{a}^{14} \mathrm{C}_{\text {carb }}\right)$, isotopic composition of carbon $\left(\delta^{13} \mathrm{C}_{\text {carb }}\right)$, and oxygen $\left(\delta^{18} \mathrm{O}\right)$. Isotopic composition of nitrogen $\left(\delta^{15} \mathrm{~N}\right)$ was analyzed in the bulk sediment samples.

For organic matter analyses, sediment samples were pre-treated with $1 \mathrm{~N} \mathrm{HCl}$ and the rest was analyzed by the Perkin Elmer 2400 Series II CHNS Analyser.

${ }^{14} \mathrm{C}$ activity of both carbonate and organic fraction was measured on a liquid scintillation counter (Perkin Elmer, Quantulus 1220) using the benzene preparation method (Horvatinčić et al. 2004). The results were corrected for $\delta^{13} \mathrm{C}$, and reported as ${ }^{14} \mathrm{C}$ activity $\left(\mathrm{a}^{14} \mathrm{C}\right)$ in percent of modern carbon (pMC) (Mook \& van der Plicht 1999), standard deviation 0.5 pMC.

$\delta^{13} \mathrm{C}$ and $\delta^{18} \mathrm{O}$ in the carbonate fraction was determined using a modified method by McCrea (1950). Samples were placed into exetainers and flushed with helium. Concentrated $\mathrm{H}_{3} \mathrm{PO}_{4}$ was added and the isotopic composition of $\mathrm{CO}_{2}$ was determined on a continuousflow Europa 20-20 ANCA-TG stable isotope ratio mass spectrometer (Europa Scientific Ltd., Crewe, UK). Isotopic ratios are expressed in standard delta notation $\left(\delta^{13} \mathrm{C}\right.$ and $\delta^{18} \mathrm{O}$ ) as per mil (\%o) deviation from the $\mathrm{V}-\mathrm{PDB}$ standard. For $\delta^{13} \mathrm{C}$ analysis of the organic fraction, dry sediment samples were soaked in $1 \mathrm{~N} \mathrm{HCl}$ overnight to remove carbonates, and then filtered on quartz-fiber filters (Whatman $\mathrm{GF} / \mathrm{F}$ ), rinsed with de-ionized water, and re-dried. The stable isotopic composition of organic carbon was determined on a continuous-flow Europa 20-20 ANCA-SL isotope ratio mass spectrometer. The same spectrometer was used to measure the isotopic composition of total nitrogen in homogenized bulk samples. Nitrogen isotope ratios are reported as $\delta^{15} \mathrm{~N}$ with respect to atmospheric $\mathrm{N}_{2}$ (air).

\section{RESULTS}

Results of each parameter measured in sediment including organic matter (OM) and its $\mathrm{C} / \mathrm{N}$ composition (Fig. 2), $\mathrm{a}^{14} \mathrm{C}$ of organic and carbonate fraction (Fig. 3), $\delta^{13} \mathrm{C}$ and $\delta^{18} \mathrm{O}$ of carbonate fraction (Fig. 4), and $\delta^{13} \mathrm{C}$ of organic fraction and $\delta^{15} \mathrm{~N}$ of total nitrogen (Fig. 5) are presented in sediment profiles for four site locations fol-
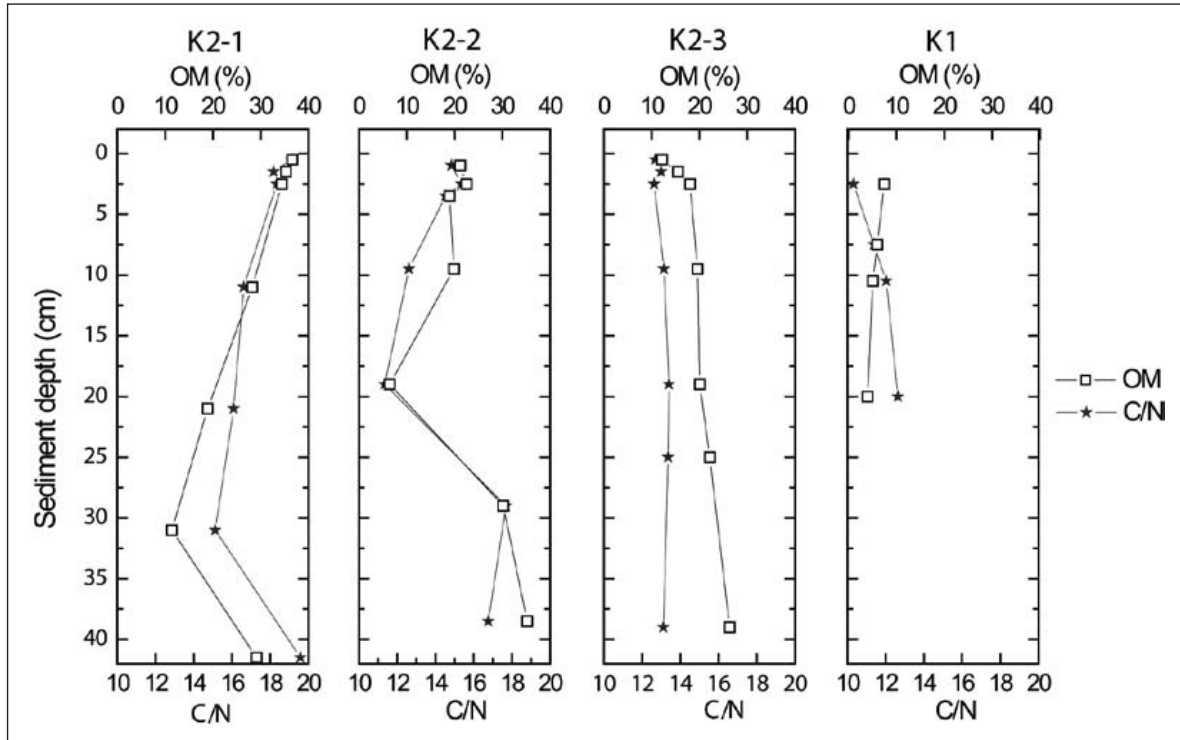

lowing the direction from the mouth of Rječica Brook to the open Lake Kozjak, i.e. from K2-1, K2-2, K2-3 to K1 (Fig. 1). The minimum and maximum values and the average values of $\mathrm{OM}, \mathrm{C} / \mathrm{N}$ and the isotopic composition of all sediment profiles are compiled in Tab. 1. Physical

Fig. 2: Organic matter (OM) content and its $\mathrm{C} / \mathrm{N}$ ratio in all sediment profiles. 
Tab. 1: Summary of the results of organic matter (OM), C/N ratios and isotopic analyses for all sediment profiles. Results are presented as the range of minimum and maximum values and the average values for each sediment core.

\begin{tabular}{l|c|c|c|c|c|c|c|c}
\hline \multirow{2}{*}{} & \multicolumn{2}{|c|}{ K2-1, Rječica Brook mouth } & \multicolumn{2}{c|}{ K2-2, 50 $\boldsymbol{m}$ from K2-1 } & \multicolumn{2}{c|}{ K2-3, 100 $\boldsymbol{m}$ from K2-1 } & \multicolumn{2}{c}{ K1, Lake Kozjak centre } \\
\cline { 2 - 9 } & range & average & range & average & range & average & range & average \\
\hline $\mathrm{OM}(\%)$ & $15.4-44.8$ & 30.8 & $6.4-35.2$ & 22.0 & $12.1-26.3$ & 19.1 & $3.9-7.4$ & 5.6 \\
\hline $\mathrm{C} / \mathrm{N}$ & $14.1-19.8$ & 17.1 & $11.3-17.7$ & 14.7 & $12.6-13.4$ & 13.0 & $10.3-12.7$ & 11.6 \\
\hline $\mathrm{a}^{14} \mathrm{C}_{\text {org }}(\mathrm{pMC})$ & $94.4-111.3$ & 101.8 & $97.5-108.5$ & 102.2 & $92.5-106.7$ & 96.4 & $85.0-91.0$ & 88.7 \\
\hline $\mathrm{a}^{14} \mathrm{C}_{\text {carb }}(\mathrm{pMC})$ & $32.3-75.7$ & 51.7 & $32.6-83.7$ & 65.6 & $54.0-64.6$ & 58.6 & $70.0-79.2$ & 72.4 \\
\hline $\mathrm{d}^{13} \mathrm{C}_{\text {org }}(\%)$ & $-29.7-(-28.2)$ & -29.0 & $-30.0-(-28.8)$ & -29.5 & $-29.7-(-27.9)$ & -28.7 & $-32.7-(-30.9)$ & -31.7 \\
\hline $\mathrm{d}^{13} \mathrm{C}_{\text {carb }}(\%)$ & $-7.5-(-3.0)$ & -6.1 & $-7.8-(-7.0)$ & -7.5 & $-8.3-(-6.9)$ & -7.7 & $-8.7-(-8.3)$ & -8.6 \\
\hline $\mathrm{d}^{18} \mathrm{O}_{\text {carb }}(\% 0)$ & $-12.1-(-8.6)$ & -11.1 & $-11.3-(-10.4)$ & -10.6 & $-11.3-(-10.2)$ & -10.8 & $-11-(-10.3)$ & -10.6 \\
\hline $\mathrm{d}^{15} \mathrm{~N}_{\text {tot }}(\% 0)$ & $-1.7-(-0.1)$ & -1.0 & $-1.7-(-1.0)$ & -1.4 & $-0.2-(+0.6)$ & 0.2 & $+1.3-(+2.4)$ & 1.8 \\
\hline
\end{tabular}

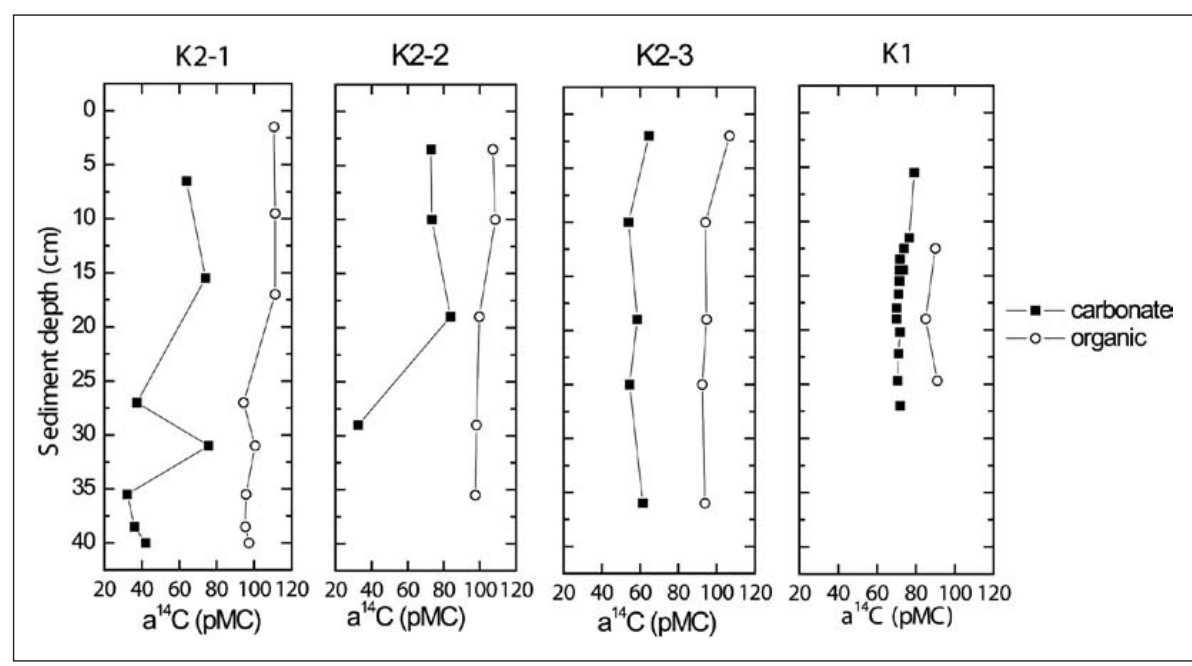

Fig. 3: ${ }^{14} \mathrm{C}$ activity $\left(a^{14} \mathrm{C}\right)$ of organic and carbonate fractions in all sediment profiles.

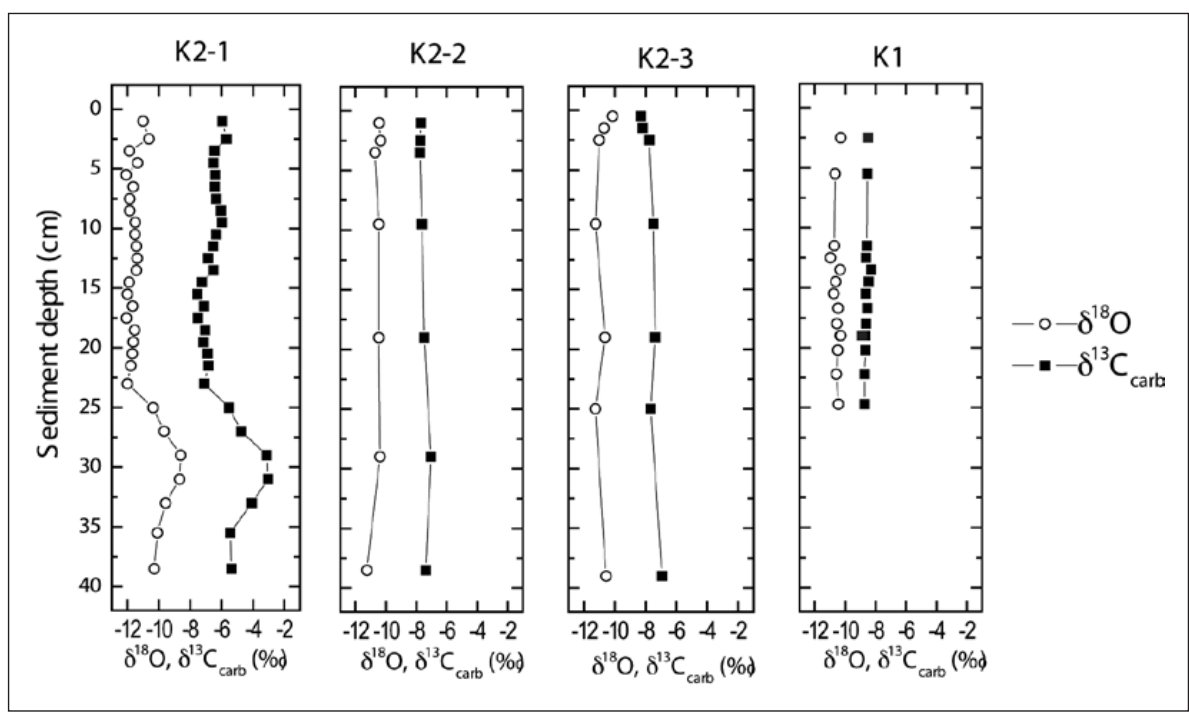

Fig. 4: $\delta^{13} \mathrm{C}$ and $\delta^{18} \mathrm{O}$ values of carbonate fraction in all sediment profiles. and chemical parameters and $\delta^{13} \mathrm{C}$ in dissolved inorganic carbonate $\left(\delta^{13} \mathrm{C}_{\mathrm{DIC}}\right)$ of surface waters at locations $\mathrm{K} 1$ and $\mathrm{K} 2$ are presented in Tab. 2 .

\section{ORGANIC MATTER AND \\ C/N COMPOSITION \\ OF SEDIMENT}

The sediment cores from all locations are homogeneous in color without distinct layers. K2 sediment cores are black colored with visible leaves and other humus particles whereas the sediment at $\mathrm{K} 1$ site is light grey, homogeneous and fine-grained material. Concentrations of $\mathrm{OM}$ and $\mathrm{C} / \mathrm{N}$ ratios of $\mathrm{OM}$ in all sediment profiles are presented in Fig. 2. OM decreases from the outflow of Rječica Brook towards the open lake (mean values): $31 \%$ at location $\mathrm{K} 2-1,22 \%$ at $\mathrm{K} 2-2,19 \%$ at K2-3, and 6\% at K1 (Tab. 1).

The steady decrease of $\mathrm{C} / \mathrm{N}$ is also observed in $\mathrm{di}-$ rection from the mouth of the Rječica Brook to the open lake. The mean values are: 17 at $\mathrm{K} 2-1,15$ at $\mathrm{K} 2-2$ and 13 at K2-3 (Tab. 1). At the K1 site mean $\mathrm{C} / \mathrm{N}$ value is 12 . For K2-3 and K1 cores distribu- 


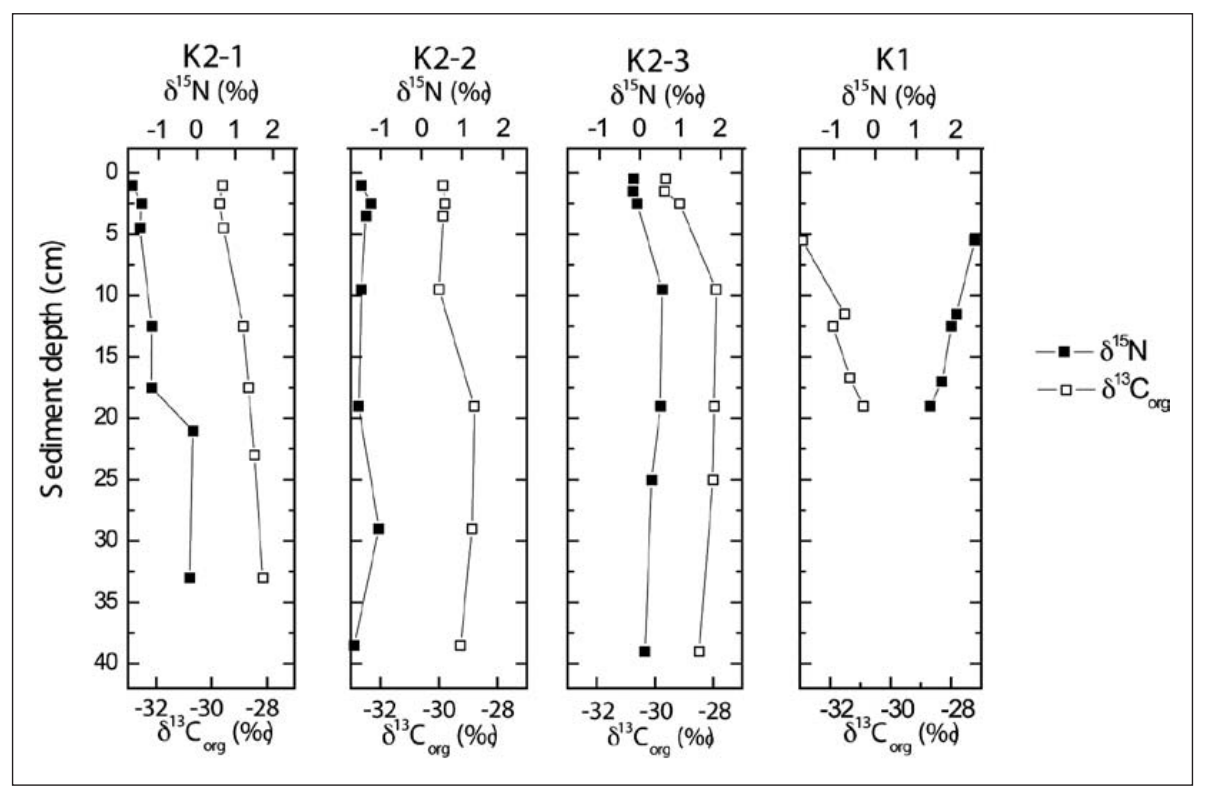

Fig. 5: $\delta^{13} \mathrm{C}$ values of organic fraction $\left(\delta^{13} C_{\text {org }}\right)$ and $\delta^{15} \mathrm{~N}$ values in all sediment profiles. tion of $\mathrm{C} / \mathrm{N}$ values along the sediment profile is mostly uniform with slight variation, while for K2-1 and K2-2 the variations of $\mathrm{C} / \mathrm{N}$ are significant. Good correlation between distribution of $\mathrm{OM}$ and $\mathrm{C} / \mathrm{N}$ values along the sediment profiles was perceived.

\section{ISOTOPIC COMPOSITION OF SEDIMENT}

The ${ }^{14} \mathrm{C}$ activity of organic $\left(\mathrm{a}^{14} \mathrm{C}_{\text {org }}\right)$ and carbonate $\left(\mathrm{a}^{14} \mathrm{C}_{\text {carb }}\right)$ fractions of the sediment profiles is shown in Figure 3. A significant difference in ${ }^{14} \mathrm{C}$ activity between carbonate and organic fraction that is the result of the carbon origin in each is obvious for all the sediments. The $\mathrm{a}^{14} \mathrm{C}_{\text {org }}$ of surface layers in all sediment cores at $\mathrm{K} 2$ locations are above 100 pMC and are on average about $\sim 10$ pMC higher than in the lower layers.

The mean values of $\mathrm{a}^{14} \mathrm{C}_{\text {carb }}$ of $\mathrm{K} 1$ and $\mathrm{K} 2$ sediment profiles increase (exception is $\mathrm{K} 2-3$ ) from $52 \mathrm{pMC}$ for $\mathrm{K} 2-1$ to 72 pMC for K1 (Tab. 1). The sediment cores closer to the Rječica Brook mouth have high a ${ }^{14} \mathrm{C}_{\text {carb }}$ variations along the sediment profile, from 32 to $76 \mathrm{pMC}$ and from 32 to 84 pMC for $\mathrm{K} 2-1$ and $\mathrm{K} 2-2$ site, respectively, while for $\mathrm{K} 2-3$ and $\mathrm{K} 1$ sediment cores the $\mathrm{a}^{14} \mathrm{C}_{\text {carb }}$ values ing are simultaneous changes in both $\delta^{13} \mathrm{C}_{\text {carb }}$ and $\delta^{18} \mathrm{O}$ between 25 and $40 \mathrm{~cm}$ depth. $\delta^{13} \mathrm{C}_{\text {carb }}$ and $\delta^{18} \mathrm{O}$ values in all other sediment profiles are rather constant with small variations in surface layers. The mean $\delta^{13} \mathrm{C}_{\text {carb }}$, similar for $\mathrm{K} 2-2$ and $\mathrm{K} 2-3,-7.5 \%$ and $-7.7 \%$, respectively, and $-8.6 \%$ for $\mathrm{K} 1$, show a decrease from the mouth to the open lake.

The $\delta^{13} \mathrm{C}$ values of organic fraction for all sediment profiles at $\mathrm{K} 2$ locations are in the range between $-28 \%$ o and $-30 \%$ (Fig. $5 \&$ Tab. 1) with similar mean $\delta^{13} \mathrm{C}_{\text {org }}$ : $-29.0 \%$ o, $-29.5 \%$ and $-28.7 \%$ o for $\mathrm{K} 2-1, \mathrm{~K} 2-2$ and $\mathrm{K} 2-3$, respectively. $\delta^{13} \mathrm{C}_{\text {org }}$ of $\mathrm{K} 1$ sediment has a mean value of $-31.7 \%$ o covering the range from $-30.9 \%$ o to $-32.7 \%$. It is observed that the $\delta^{13} \mathrm{C}_{\text {org }}$ values for all sediment profiles steadily decrease in the surface layers.

The $\delta^{15} \mathrm{~N}$ values indicate the low content of ${ }^{15} \mathrm{~N}$ with slight variations in all sediment profiles (Fig. 5) and with steady increase of the mean $\delta^{15} \mathrm{~N}$ from $\mathrm{K} 2-1 \quad(-1.0 \%$ ) to $\mathrm{K} 1(1.8 \% \mathrm{o})$. In all $\mathrm{K} 2$ sediments the change of $\delta^{15} \mathrm{~N}_{\text {tot }}$ values along the sediment profile follows the change in $\delta^{13} C_{\text {org, }}$, with slight decrease in values in the surface sediments.

\section{DISCUSSION}

Water analyses at both locations (Tab. 2) show the higher values for conductivity, bicarbonate, nitrate and dissolved organic carbon (DOC) concentrations at K2 site. That can be explained by water input of Rječica Brook flowing through the area covered by forest and so caring landderived or soil based runoff. Also the low value of $\delta^{13} C_{D I C}$ in Rječica Brook (mean value -11.9\%o), compared with $\delta^{13} C_{\text {DIC }}$ of center Kozjak Lake (mean value - $10.4 \%$ ), suggests that the fraction of carbon in DIC originating from the $\mathrm{CO}_{2}$ plant respiration and/or soil/humus is higher at K2 than at K1 (Meyers 2003; Leng \& Marshall 2004; Horvatinčić et al. 2008). Generally low concentration of 
Tab. 2: Results of physical and chemical measurements of surface water presented as a mean values and the range of minimum and maximum values including all seasonal measurements.

\begin{tabular}{|c|c|c|c|c|c|c|c|c|c|}
\hline Location & $\begin{array}{c}\text { Temperature } \\
\left({ }^{\circ} \mathrm{C}\right)\end{array}$ & $\mathrm{pH}$ & $\begin{array}{l}\text { Conductivity } \\
\qquad\left(\mu \mathrm{Scm}^{-1}\right)\end{array}$ & $\begin{array}{c}\mathrm{O}_{2} \\
\left(m \mathrm{gl}^{-1}\right)\end{array}$ & $\begin{array}{c}\mathrm{HCO}_{3} \\
\left(\mathrm{mmolL}^{-1}\right)\end{array}$ & $\begin{array}{l}\mathrm{NH}_{4} / \mathrm{N} \\
\left(\mathrm{mgl}^{-1}\right)\end{array}$ & $\begin{array}{l}\mathrm{NO}_{3} / \mathrm{N} \\
\left(\mathrm{mgl}^{-1}\right)\end{array}$ & $\begin{array}{c}D O C \\
\left(m g C L^{-1}\right)\end{array}$ & $\begin{array}{l}\delta^{13} C_{D I C} \\
(\% 0)\end{array}$ \\
\hline Rječica mouth, K2 & $\begin{array}{c}8.8 \\
4.2-10.4\end{array}$ & $\begin{array}{c}8.2 \\
8.0-8.3\end{array}$ & $\begin{array}{c}503 \\
494-512\end{array}$ & $\begin{array}{c}10.2 \\
8.1-11.3\end{array}$ & $\begin{array}{c}5.4 \\
5.2-5.5\end{array}$ & $\begin{array}{c}0.04 \\
0.01-0.18\end{array}$ & $\begin{array}{c}0.9 \\
0.7-1.0\end{array}$ & $\begin{array}{c}1.3 \\
1.0-2.1\end{array}$ & $\begin{array}{c}-11.9 \\
-12.5-(-11.5)\end{array}$ \\
\hline Lake Kozjak, K1 & $\begin{array}{c}12.6 \\
3.6-21.6\end{array}$ & $\begin{array}{c}8.3 \\
8.1-8.4\end{array}$ & $\begin{array}{c}390 \\
377-404\end{array}$ & $\begin{array}{c}10.1 \\
8.1-12.5\end{array}$ & $\begin{array}{c}3.8 \\
3.5-4.2\end{array}$ & $\begin{array}{c}0.03 \\
0.01-0.05\end{array}$ & $\begin{array}{c}0.6 \\
0.4-0.9\end{array}$ & $\begin{array}{c}1.1 \\
0.7-2.0\end{array}$ & $\begin{array}{c}-10.4 \\
-11.7-(-9.7)\end{array}$ \\
\hline
\end{tabular}

nutrients and DOC at both locations do not indicate anthropogenic pollution in waters.

\section{RECORDS IN ORGANIC FRACTION OF SEDIMENT}

Concentration of organic fraction in sediments (Fig. 2) close to the mouth of Rječica Brook (K2 locations) is much higher than in the centre of the Lake Kozjak at $\mathrm{K} 1$, which is approximately $1 \mathrm{~km}$ away from the Rječica mouth (Fig. 1). Also the sediment color is related to the content of organic matter, black colored at K2 and light grey at K1 location. Steady decrease of OM mean values in the sediment profiles towards the open lake is also followed by a decrease of $\mathrm{C} / \mathrm{N}$ mean values in the same direction, from 17 at K2-1 to 12 at K1 (Tab. 1 \& Fig. 2). The $\mathrm{C} / \mathrm{N}$ ratio in the sediment is a good indicator of organic carbon sources; for example, organic matter from lake algae has $\mathrm{C} / \mathrm{N}$ values between 4 and 10 , and land plants have usually $\mathrm{C} / \mathrm{N}$ ratio of 20 and more (Brenner et al. 1999; Herczeg et al. 2001; Meyers 2003). In our case the $\mathrm{C} / \mathrm{N}$ values show that the $\mathrm{OM}$ in the sediments is the mixture of the allochthonous matter that decreases towards the open lake and autochthonous OM which dominates in the lake centre.

Additionally, the mean $\delta^{13} \mathrm{C}_{\text {org }}$ values of all $\mathrm{K} 2$ sediment profiles are similar (Fig. 5 \& Tab. 1), while at K1 sediment the mean $\delta^{13} \mathrm{C}_{\text {org }}$ value is more negative. The relation between $\delta^{13} \mathrm{C}_{\text {org }}$ and $\mathrm{C} / \mathrm{N}$ atomic ratios for all sediment profiles (Fig. 6) shows distinction between K1 and $\mathrm{K} 2$ sites due to diminishing of the Rječica Brook influence from K2 to K1. The K1 sediment shows characteristics of sedimentary organic matter produced in aquatic environment with lower $\mathrm{C} / \mathrm{N}$ ratios and lower $\delta^{13} \mathrm{C}_{\mathrm{org}}$. It indicates that the main fraction of organic matter probably originates from in-lake processes, such as algal photosynthesis (Brenner et al. 1999; Meyers 2003). In contrast, $\mathrm{K} 2$ sediments cover a narrow range of $\delta^{13} \mathrm{C}_{\text {org }}$ values and are very similar to the $\delta^{13} \mathrm{C}$ values of terrestrial plants in the Plitvice Lakes area which varies between $-28 \%$ and $-29 \%$ (Marčenko et al. 1989). C/N values of $\mathrm{K} 2$ sediments decrease with increase in distance from the Rječica Brook inflow as discussed earlier. Results show that organic fraction of $\mathrm{K} 2$ sediments is a mixture of organic matter of different sources with a dominant

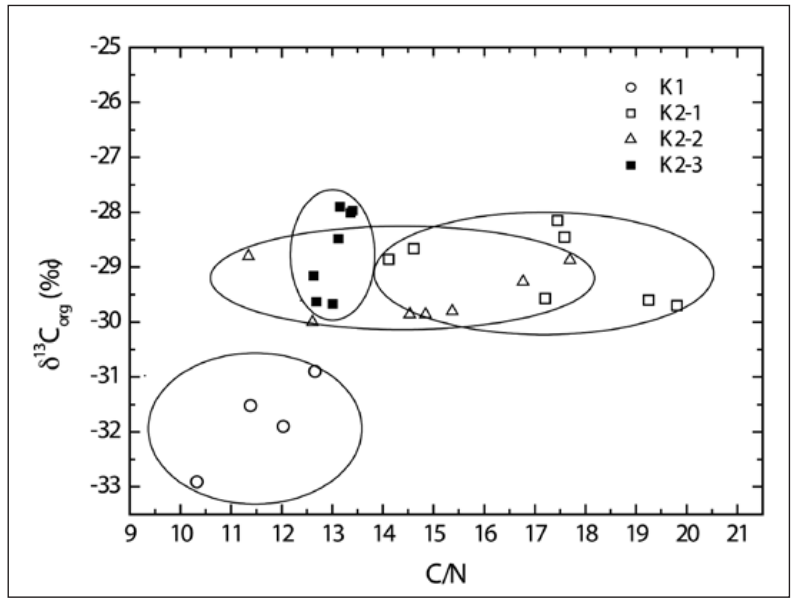

Fig. 6: Relation between $\delta^{13} \mathrm{C}$ and $\mathrm{C} / \mathrm{N}$ ratio in organic fraction for all sediment profiles.

terrestrial organic fraction at K2-1 and increasing influence of aquatic organic fraction in off-shore direction as recorded at $\mathrm{K} 2-3$. It is also observed that the $\delta^{13} \mathrm{C}_{\text {org }}$ values for all sediment profiles steadily decrease in the surface layers that could be a consequence of the increase in algal productivity and ${ }^{13} \mathrm{C}$ depleted submerged plants (Marčenko et al. 1989) in the Lake Kozjak. Since the waters of Plitvice Lakes have low concentrations of nutrients (Horvatinčić et al. 2006), the possible reason of increase of productivity could be a slight increase of the surface water temperature of the Plitvice Lakes in the last three decades. Recent mean annual temperatures of the surface lake waters for period 2002-2006 were 0.5 to $2^{\circ} \mathrm{C}$ higher than for period 1980-1985 (Horvatinčić et al. 2008). However, decreasing trend of $\delta^{13} \mathrm{C}_{\text {org }}$ values can be partly caused by the contribution of isotopically depleted $\mathrm{CO}_{2}$ from fossil fuel combustion, i.e. the Suess effect. The influence of the Suess effect to $\delta^{13} \mathrm{C}$ values in recent lake sediments was also observed by Vreča \& Muri (2006) and Verburg (2007) using model proposed by Schelske \& Hodell (1995).

$\delta^{15} \mathrm{~N}$ values between $1.3 \%$ and $2.4 \% 0$ measured in $\mathrm{K} 1$ core (Fig. 5) are generally referred as the result of atmospheric nitrogen utilized by nitrogen-fixing cyanobacteria (Talbot \& Laerdal 2000). Cyanobacteria and other microbial organisms play an important role in the 
process of tufa/sediment precipitation in the waters of the Plitvice Lakes (Chafetz et al. 1994). The negative $\delta^{15} \mathrm{~N}$ values measured in $\mathrm{K} 2$ sediments might have originated from soil nitrogen input (Pichlmayer et al. 1998; Kendall 1998; Talbot 2001; Sah \& Brumme 2003; Kanduč et al. 2008) because soil run-off by the Rječica Brook is dominant. In all $\mathrm{K} 2$ sediments, the change of $\delta^{15} \mathrm{~N}$ values along the sediment profile follows the change in $\delta^{13} \mathrm{C}_{\text {org }}$, with slight decrease in values in the surface sediments. Changes of $\delta^{15} \mathrm{~N}$ values in $\mathrm{K} 2$ cores could indicate organic matter degradation processes (Hodell \& Schelske 1998; Brenner et al. 1999), and also varied sources of nitrogen in the sediment (Brenner et al. 1999; Herzeg et al. 2001; Vreča \& Muri 2006). More positive $\delta^{15} \mathrm{~N}$ values in K2-3 core (mean $0.2 \%$ ) follow the decreasing trend of terrestrial influence in off-shore direction. The slight increase of $\delta^{15} \mathrm{~N}$ values, decrease of $\mathrm{C} / \mathrm{N}$ and $\delta^{13} \mathrm{C}_{\text {org }}$ values in the $\mathrm{K} 1$ sediment surface is a probable indication of enhanced algal productivity but more detailed research is necessary to confirm this assumption. Similar indicators of enhanced algal productivity were described by Brenner et al. (1999), Teranes \& Bernasconi (2000), and Herczeg et al. (2001).

The $\mathrm{a}^{14} \mathrm{C}_{\text {org }}$ of sediment cores reflects the ${ }^{14} \mathrm{C}$ activity of atmospheric $\mathrm{CO}_{2}$ and/or environmental vegetation including terrestrial and aquatic plants. In K2 sediments the $\mathrm{a}^{14} \mathrm{C}_{\text {org }}$ is in the range 92-111 pMC (Tab. 1 \& Fig. 3 ) and is significantly higher than in the $\mathrm{K} 1$ sediment (85-91 pMC). It is expected that in $\mathrm{K} 1$ sediment (centre of the Lake, Fig. 1) the organic matter is predominantly autochthonous one, formed by photosynthesis process of aquatic plants which use partly the $\mathrm{CO}_{2}$ from DIC in water, so called hard-water effect (Marčenko et al. 1989; Geyh et al. 1998). This is confirmed by the $\mathrm{a}^{14} \mathrm{C}$ values of the Plitvice Lakes aquatic plants (range 81-92 pMC, Marčenko et al. 1989) and of the Kozjak Lake DIC (range 80-85 pMC, Srdoč et al. 1986a). The $\mathrm{a}^{14} \mathrm{C}_{\text {org }}$ values higher at $\mathrm{K} 2$ than at $\mathrm{K} 1$ sites (Tab. 1) indicate the influence of terrestrial organic matter transported by Rječica Brook but also of the macrophites remnants growing at K2. The $\mathrm{a}^{14} \mathrm{C}$ of terrestrial plants at K2 (beech leaves and abies needles collected in 2005-2006, 105 pMC and 110 pMC, respectively) is in good correlation with $\mathrm{a}^{14} \mathrm{C}_{\text {org }}$ of $\mathrm{K} 2$ sediments in the upper layers.

An increase in $\mathrm{a}^{14} \mathrm{C}_{\text {org }}$ of $~ 10 \%$ from $95-97 \mathrm{pMC}$ in the lower layers to the $\mathrm{a}^{14} \mathrm{C}_{\text {org }}$ of $106-111 \mathrm{pMC}$ in surface layers at K2 sediment cores (for K2-1 at 17-27 cm, for $\mathrm{K} 2-2$ at $10-20 \mathrm{~cm}$, and for $\mathrm{K} 2-3$ at $5-10 \mathrm{~cm}$ from the surface, Tab. 1 \& Fig. 3) could be attributed to the global contamination of atmospheric $\mathrm{CO}_{2}$ with ${ }^{14} \mathrm{C}$ produced due to nuclear bomb tests in the last century. The atmospheric ${ }^{14} \mathrm{C}$ activity, with almost $100 \%$ increase in 1963 (Levine \& Kromer 1997), was also observed in the tree rings collected in the Plitvice Lakes area (Krajcar Bronić et al. 1998) and in the lake sediments from different Plitvice Lakes, in organic as well in carbonate fractions (Horvatinčić et al. 2008; Srdoč et al. 1992). The response to bomb-induced ${ }^{14} \mathrm{C}$ in the atmospheric $\mathrm{CO}_{2}$ in the sediments, seen as a peek in $\mathrm{a}^{14} \mathrm{C}$, is damped and decades-delayed because of complex geochemical processes involved in sediment formation (Srdoč et al. 1992; Genty et al. 1998; Horvatinčić et al. 2008). In all K2 profiles the ${ }^{14} \mathrm{C}$ activity peak was not observed probably because of relatively high sedimentation rates, but also because of possible physical mixing of sediments and transport of terrestrial organic matter by Rječica Brook. Assuming that the layers above $27 \mathrm{~cm}, 20 \mathrm{~cm}$ and $10 \mathrm{~cm}$ for K2-1, K2-2 and K2-3, respectively, belong to the period after 1963, the sedimentation rate for each site can be estimated as follows: $6.7 \mathrm{~mm} / \mathrm{yr}$ for K2-1, $4.2 \mathrm{~mm} / \mathrm{yr}$ for K2-2 and $2.5 \mathrm{~mm} / \mathrm{yr}$ for K2-3. Previous investigation of Kozjak Lake sediment in the lake centre (close to K1 location) estimated the sedimentation rate of $0.8 \mathrm{~mm} / \mathrm{yr}$ by ${ }^{14} \mathrm{C}$ (Srdoč et al. 1986b) and by using ${ }^{210} \mathrm{~Pb}$ method the mass accumulation rate of $0.8 \mathrm{~kg} / \mathrm{m}^{2}$ yr (Horvatinčić et al. 2008). Although the sedimentation rates for $\mathrm{K} 2$ sites can be used only as estimated values, there is a consistent decrease of sedimentation rates towards the open lake which can be explained by strong influence of terrestrial material run-off by Rječica Brook.

\section{RECORDS IN CARBONATE FRACTION OF SEDIMENT}

Previous investigation of chemical composition of sediments (Horvatinčić et al. 2006) showed significant differences between $\mathrm{K} 1$ and $\mathrm{K} 2$ sediments. The mineral fraction of sediment K1 represents $>90 \%$ and consists mainly of calcite $(>80 \%)$, over quartz and dolomite while at the confluence of Rječica Brook (K2 sites, mineral fraction $60-85 \%)$ the concentration of calcite is $<60 \%$ with the similar proportion of calcite, dolomite and quartz in the surface layer. The isotope analyses of carbonate fraction in all sediment cores are presented in Fig. $3\left(\mathrm{a}^{14} \mathrm{C}_{\text {carb }}\right)$ and Fig. $4\left(\delta^{13} \mathrm{C}_{\text {carb }}\right.$ and $\left.\delta^{18} \mathrm{O}\right)$. Carbon isotopes $\left(\mathrm{a}^{14} \mathrm{C}_{\text {carb }}\right.$ and $\delta^{13} \mathrm{C}_{\text {carb }}$ ) of the Plitvice Lakes sediments mainly originate from the DIC in water (Srdoč et al. 1986a; Horvatinčić et al. 2003) as a result of geochemical processes in the groundwater that feeds the lakes (Krajcar Bronić et al. 1992). Moreover, this is also the influence of carbon isotope exchange processes between DIC and atmospheric $\mathrm{CO}_{2}$ that were reflected in the steady downstream increase of $\mathrm{a}^{14} \mathrm{C}_{\mathrm{DIC}}$ and $\delta^{13} \mathrm{C}_{\mathrm{DIC}}$ values in the Plitvice Lakes water (Srdoč et al. 1986a). The lower $\mathrm{a}^{14} \mathrm{C}_{\text {carb }}$ mean values for $\mathrm{K} 2$ sediments with steady increase from Rječica Brook mouth (51.7 pMC at K2-1) to the open lake (72.4 pMC at K1) indicate the influence of the eroded carbonate frac- 
tion originating from the catchment area of the Rječica Brook. Moreover, the highest $\delta^{13} \mathrm{C}_{\text {carb }}$ mean value of $-6.1 \%$ for K2-1 sediment core (Tab. 1 \& Fig. 4) indicates the highest fraction of allogenic mineral carbonate, while in $\mathrm{K} 1$ sediment the mean $\delta^{13} \mathrm{C}_{\text {carb }}$ of $-8.6 \%$ is the typical value of lake sediment and/or tufa deposits precipitated from DIC in water of the Plitvice Lakes (Srdoč et al. 1986a; Horvatinčić et al. 2003). Also the lower $\delta^{13} C_{\text {DIC }}$ values in water samples from Rječica Brook (mean value $-11.9 \%$ ), compared with center Kozjak Lake K1 (mean value $-10.4 \%$ ) (Tab. 2), suggest a higher fraction of DIC originating from the $\mathrm{CO}_{2}$ plant respiration from the soil/ humus at K2 site (Meyers 2003; Leng \& Marshall 2004; Horvatinčič et al. 2008).

Correlation of $\delta^{13} \mathrm{C}_{\text {carb }}$ and $\delta^{18} \mathrm{O}$ values (Fig. 7) shows that sediments of $\mathrm{K} 2-2$ and $\mathrm{K} 2-3$ form groups with a similar range of $\delta^{18} \mathrm{O}$ and $\delta^{13} \mathrm{C}_{\text {carb }}$ values, but more dispersed than $\mathrm{K} 1$ indicating possible mixing of carbonate sources of various origins, i.e. authigenic and

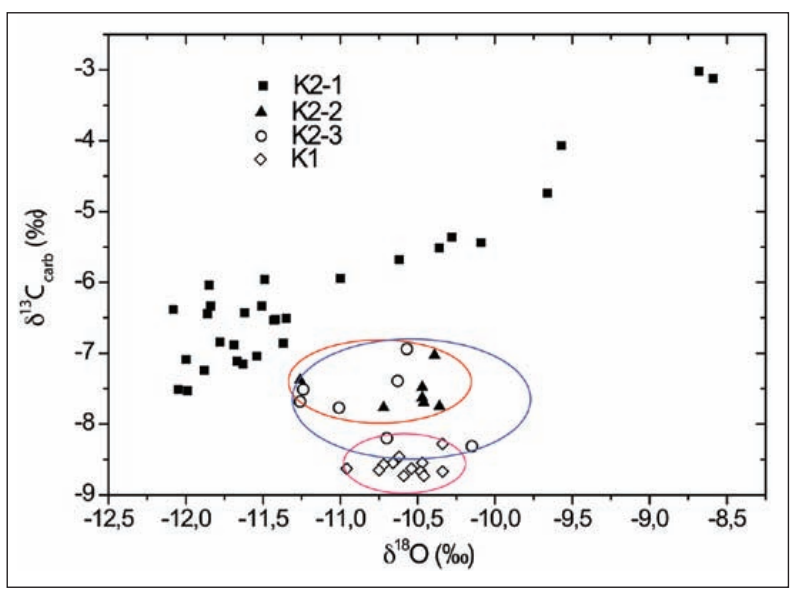

Fig. 7: Relation between $\delta^{13} \mathrm{C}$ and $\delta^{18} \mathrm{O}$ in carbonate fraction of all sediment profiles.

allogenic fraction. The most dispersed values for K2-1 sediment show that in the sediment formation the mixing of authigenic and allogenic fraction has an important role, which was also proved by variations of $\mathrm{a}^{14} \mathrm{C}_{\text {carb }}$ in the same sediment profile.

Significant variations of $\mathrm{a}^{14} \mathrm{C}_{\text {carb }}$ and $\delta^{13} \mathrm{C}_{\text {carb }}$ and $\delta^{18} \mathrm{O}$ in the same layers of the K2-1 sediment core $(25-35 \mathrm{~cm}$, Figs. 3 \& 4), indicate different fractions of eroded material in sediment layers transported by the Rječica Brook. In other sediment profiles the $\mathrm{a}^{14} \mathrm{C}_{\text {carb }}$ and $\delta^{13} \mathrm{C}_{\text {carb }}$ values are more uniform, but the slight increase of $\mathrm{a}^{14} \mathrm{C}_{\text {carb }}$ is observed in the upper layers of all sediments. The change of $\mathrm{a}^{14} \mathrm{C}_{\text {carb }}$ coincides with the increase of $\mathrm{a}^{14} \mathrm{C}_{\text {org }}$ in the same layers (Fig. 3) what could be again a consequence

Fig. 8: Mean values of different chemical and isotopic parameters for all sediment profiles in correlation with distance from the mouth of Rječica Brook. The linear correlation and $R^{2}$ values between measured parameters and distance from the Rječica Brook mouth at points K2-1, K2-2 and K2-3 are presented. 
of the global ${ }^{14} \mathrm{C}$ contamination of atmospheric $\mathrm{CO}_{2}$ by the thermonuclear weapon tests described earlier.

\section{DISTRIBUTION OF ALLOGENIC AND AUTHIGENIC FRACTION}

The summary of the results of different chemical and isotopic parameters used for study of contribution of the stream of Rječica Brook to the composition of the lake sediment is presented in Fig. 8. The results, mean values for each sediment profile, are presented in correlation with distance from the Rječica Brook mouth. The liner correlations between measured parameters and distance from the Rječica Brook mouth at K2-1, K2-2 and K2-3 sites are also presented.

Change of $\mathrm{OM}$ and $\mathrm{C} / \mathrm{N}$ ratio shows good linear correlation $\left(R^{2}=0.96, p=0.09\right)$ for the sediments close to Rječica mouth, first $\sim 150 \mathrm{~m}$, and somewhat worse correlation for change of $\delta^{13} \mathrm{C}_{\text {carb }}\left(\mathrm{R}^{2}=0.8, \mathrm{p}=0.26\right)$ and $\mathrm{a}^{14} \mathrm{C}_{\text {org }}$ $\left(R^{2}=0.7, p=0.35\right)$. Changes of $\delta^{15} \mathrm{~N}, \delta^{13} \mathrm{C}_{\text {org }}$ and $\mathrm{a}^{14} \mathrm{C}_{\text {carb }}$ values show weak correlation with distance. The values of all parameters are quite different for the sediment in the Lake centre, $\sim 1000 \mathrm{~m}$ away from the Rječica Brook mouth. In this point the influence of Rječica Brook is not expected and these values confirm the authigenic origin of the sediment, i.e. precipitation of carbonate fraction mostly from DIC in water, and production of organic matter mainly by photosynthesis process.

Using the values which are characteristic for authigenic and allogenic fractions for carbonate and organic matter in the sediment we tried to approximate the distribution of authigenic and allogenic fractions regarding the distance from the Rječica Brook mouth. For this calculation we used the parameters which showed the best correlation (Fig. 8), i.e. $\delta^{13} \mathrm{C}_{\text {carb }}$ values for carbonate fraction and $\mathrm{C} / \mathrm{N}$ values for organic fraction.

For carbonate fraction we used the mean values of $\delta^{13} \mathrm{C}_{\text {carb }}$ and $\delta^{13} \mathrm{C}_{\mathrm{DIC}}$ for the $\mathrm{K} 2$ and $\mathrm{K} 1$ sites, and assuming equilibrium conditions for calcite precipitation, we calculate the approximate ratios of allogenic and authigenic fractions in sediment at each site. The equilibrium fractionation $\varepsilon$ between DIC and precipitated calcite is about $1.5 \%$ in the range of $\mathrm{pH}(8.2-8.3)$ and temperature $\left(8.8-12.6{ }^{\circ} \mathrm{C}\right)$ typical for Kozjak Lake water at $\mathrm{K} 1$ and $\mathrm{K} 2$ sites (Tab. 2). Since $\delta^{13} \mathrm{C}$ of DIC is $-11.9 \%$ and $-10.4 \%$ o on average in Rječica mouth K2, and Lake Kozjak K1, respectively, the carbonate precipitated from Rječica DIC and Kozjak DIC under equilibrium conditions would have $\delta^{13} \mathrm{C}$ value of $-10.4 \%$ and $-8.9 \%$, respectively. $\mathrm{A}$ simple mixing calculation with mineral carbonate $\left(\delta^{13} \mathrm{C}\right.$ of $0 \%$ ) would indicate an approximate value of $\sim 60 \%$ of authigenic carbonate in K2-1 sediment profile, $\sim 70 \%$ in $\mathrm{K} 2-2, \sim 75 \%$ in $\mathrm{K} 2-3$, and $~ 95 \%$ in $\mathrm{K} 1$ sediment profile. This calculation confirms that carbonate fraction of sediment in the centre of Lake Kozjak K1 precipitates almost completely from DIC in water, whereas in the Rječica Brook mouth carbonate fractions are composed of authigenic and allogenic fractions in different ratios. The allogenic fraction decreases with distance from the Rječica mouth.

For calculation of allogenic and authigenic fraction in organic matter of the sediment we used mean values of $\mathrm{C} / \mathrm{N}$ for each sediment (Tab. 1) and assumed that $\mathrm{C} / \mathrm{N}$ value of aquatic plant is 8 (Meyers 1994) and $\mathrm{C} / \mathrm{N}$ of terrestrial plant (mixture of beech leaves and abies needles) is 30 (Meyers 1994; Rodin \& Bazilevich 1967). A simple mixing calculation would indicate an approximate value of $\sim 60 \%$ of authigenic OM in K2-1 sediment profile, $\sim 70 \%$ in $\mathrm{K} 2-2, \sim 75 \%$ in $\mathrm{K} 2-3$ and $\sim 85 \%$ in K1. This calculation again confirms, such as in carbonate fraction of sediment, that authigenic fraction increases with the distance from the Rječica Brook mouth and in the centre of the Lake the OM is mostly of aquatic plant (photosynthesis) origin, i.e. authigenic.

\section{CONCLUSIONS}

Chemical and isotopic analyses of lake sediments indicated that the Rječica Brook was the main supplier of terrestrial material in the inflow area to the Kozjak Lake. Decreasing trend of the fractions of terrestrial matter (both organic and carbonate) in lake sediment in off-shore direction is evident by values of $\mathrm{OM}$ content, $\mathrm{C} / \mathrm{N}$ values and isotope values for $\mathrm{a}^{14} \mathrm{C}_{\text {org }}, \mathrm{a}^{14} \mathrm{C}_{\text {carb }}, \delta^{13} \mathrm{C}_{\text {org }}, \delta^{13} \mathrm{C}_{\text {carb }}$ and $\delta^{15} \mathrm{~N}$. All parameters showed the strong influence of allogenic fraction $\sim 150 \mathrm{~m}$ away from the mouth of the Rječica Brook.
Authigenic and allogenic fractions of sediments were calculated using $\delta^{13} \mathrm{C}_{\text {carb }}$ and $\mathrm{C} / \mathrm{N}$ values for carbonate and organic fraction of the sediment, respectively. The obtained values showed the significant increase of authigenic fraction from Rječica Brook mouth to the open Lake direction at the distance of $\sim 150 \mathrm{~m}$ : from $\sim 60 \%$ to $75 \%$ for carbonate fraction, and from $\sim 60 \%$ to $\sim 75 \%$ for organic fraction. In the Lake centre, $\sim 1000 \mathrm{~m}$ away from the Rječica mouth the calculated values of authigenic fraction were $\sim 95 \%$ and $\sim 85 \%$ for carbonate 
and organic fraction, respectively, confirming mostly the authigenic origin of the sediment and no influence of the Rječica Brook run-off.

The global anthropogenic ${ }^{14} \mathrm{C}$ peak at $1963 / 64$ in the biosphere is visible in the sediments as a slight increase of $\sim 10 \%$ of $\mathrm{a}^{14} \mathrm{C}_{\text {org }}$ in the surface layers. The steady decrease of the $\delta^{13} \mathrm{C}_{\text {org }}$ with decreasing depth in all sediment profiles might be a consequence of the increase in algal productivity in the last decades but might also be a contribution of fossil fuel combustion.

The estimated sedimentation rates in the Kozjak Lake with decreasing values from $6.7 \mathrm{~mm} / \mathrm{yr}$ close to the mouth to $0.8 \mathrm{~mm} / \mathrm{yr}$ at the Lake centre also showed strong influence of terrestrial fraction run-off via Rječica Brook. As the consequence, the increase of allogenic fraction in the lake sediment, e.g. organic material originating from the catchment area enhances the growth of macrophytes and therefore accelerates the eutrophication process in this part of the lake.

The comprehensive chemical and isotopic study of the lake sediments in the Kozjak Lake does not indicate significant changes in last 100 years caused by anthropogenic activity, i.e. increased number of tourists in the area. The main nutrient supplier inside the Rječica Bay of the Lake Kozjak is stream of Rječica Brook causing increased growth of macrophytes in the lake.

\section{ACKNOWLEDGEMENTS}

We are grateful to A. Novosel and B. Jalžić for diving for the sediment cores. This work was supported by the Project with the Plitvice Lakes National Park and by the Projects 0098014 and 098-0982709-2741 by the Ministry of Science, Education and Sport of the Republic of
Croatia. In Slovenia results were obtained through the research programme "Cycling of substances in the environment, mass balances, modeling of environmental processes and risk assessment" financially supported by the Slovenian Research Agency.

\section{REFERENCES}

Babinka, S. 2007: Multi-tracer study of karst waters and lake sediments in Croatia and Bosnia-Herzegovina: Plitvice Lakes National Park and Bihać area.- PhD thesis. Rheinische Friedrich-Wilhelms-Universität Bonn, pp. 167.

Brenner, M., Whitmore, T.J., Curtis, J.H., Hoddel, D.A. \& C.L. Schelske, 1999: Stable isotope $\left(\delta^{13} \mathrm{C}\right.$ and $\left.\delta^{15} \mathrm{~N}\right)$ signatures of sedimented organic matter as indicators of historic lake trophic state.- Journal of Paleolimnology, 22, 205-221.

Chafetz, H., Srdoč, D. \& N. Horvatinčić, 1994: Early diagenesis of Plitvice Lakes waterfall and barrier travertine deposits.- Géographie Physique et Quaternaire, 48, 245-255.

Genty, D., Vokal, B., Obelić, B. \& M. Massault, 1998: Bomb ${ }^{14} \mathrm{C}$ time history recorded in two modern stalagmites - importance for soil organic matter dynamics and bomb ${ }^{14} \mathrm{C}$ distribution over continents.Earth and Planetary Science Letters, 160, 795-809.

Geyh, M.A., Schotterer, U. \& M. Grosjean, 1998: Temporal changes of the ${ }^{14} \mathrm{C}$ reservoir effect in lakes.- $\mathrm{Ra}$ diocarbon, 40, 921-931.
Herczeg, A.L., Smith, A.K. \& J.C. Dighton, 2001: A 120 year record of changes in nitrogen and carbon cycling in Lake Alexandria, South Australia: C:N, $\delta^{15} \mathrm{~N}$ and $\delta^{13} \mathrm{C}$ in sediments.- Applied Geochemistry, 16, 73-84.

Hodell, D.A. \& C.L. Schelske, 1998: Production, sedimentation, and isotopic composition of organic matter in Lake Ontario.- Limnology and Oceanography, 43, 200-214.

Horvatinčić, N., Krajcar Bronić, I. \& B. Obelić, 2003: Differences in the ${ }^{14} \mathrm{C}$ age, $\delta^{13} \mathrm{C}$ and $\delta^{18} \mathrm{O}$ of Holocene tufa and speleothem in the Dinaric Karst.- Palaeogeography Palaeoclimatology Palaeoecology, 193, 139-157.

Horvatinčić, N., Barešić, J., Krajcar Bronić, I. \& B. Obelić, 2004: Measurement of low ${ }^{14} \mathrm{C}$ activities in liquid scintillation counter in the Zagreb Radiocarbon Laboratory.- Radiocarbon, 46, 105-116.

Horvatinčić, N., Briansó, J.L., Obelić, B., Barešić, J. \& I. Krajcar Bronić, 2006: Study of pollution of the Plitvice Lakes by water and sediment analyses.- Water Air and Soil Pollution, Focus 6, 475-485. 
Horvatinčić, N., Barešić, J., Babinka, S., Obelić, B., Krajcar Bronić, I., Vreča, P. \& A. Suckow, 2008: Towards a deeper understanding how carbonate isotopes $\left({ }^{14} \mathrm{C},{ }^{13} \mathrm{C},{ }^{18} \mathrm{O}\right)$ reflect environmental changes: $\mathrm{A}$ study with recent ${ }^{210} \mathrm{~Pb}$ dated sediments of the Plitvice lakes, Croatia.- Radiocarbon, 50, 233-253.

Kanduč, T., Kocman, D. \& N. Ogrinc, 2008: Hydrogeochemical and stable isotope characteristics of the River Idrijca (Slovenia), the boundary watershed between the Adriatic and Black Seas.- Aquatic Geochemistry, 14, 239-262.

Kendall, C., 1998: Tracing nitrogen sources and cycles in catchments.- In: Kendall, C. \& J.J. McDonell (eds.) Isotope Tracers in Catchment Hydrology. Elsevier, pp. 519-576, Amsterdam.

Krajcar Bronić, I., Horvatinčić, N., Srdoč, D. \& B. Obelić, 1992: Experimental determination of the ${ }^{14} \mathrm{C}$ initial activity of calcareous deposits.- Radiocarbon, 34, 593-601.

Krajcar Bronić, I., Horvatinčić, N. \& B. Obelić, 1998: Two decades of environmental isotope record in Croatia: Reconstruction of the past and prediction of future levels.- Radiocarbon, 40, 399-416.

Lamb, A.L., Vane, C.H., Wilson, G.P., Rees, J.G. \& V.L. Moss-Hayes, 2007: Assessing $\delta^{13} \mathrm{C}$ and $\mathrm{C} / \mathrm{N}$ ratios from organic material in archived cores as Holocene sea level and palaeoenvironmental indicators in the Humber Estuary, UK.- Marine Geology, 244, 109-128.

Leng, M.J. \& J.D. Marshall, 2004: Paleoclimate interpretation of stable isotope data from lake sediment archives.- Quaternary Science Reviews, 23, 811-831.

Levin, I. \& B. Kromer, 1997: Twenty years of high precision atmospheric ${ }^{14} \mathrm{CO}_{2}$ observations at Schauinsland station, Germany.- Radiocarbon, 39, 205218.

Lojen, S., Dolenec, T., Vokal, B., Cukrov, N., Mihelčić, G. \& W. Papesch, 2004: C and O stable isotope variability in recent freshwater carbonates (River Krka, Croatia).- Sedimentology, 51, 361-375.

Marčenko, E., Srdoč, D., Golubić, S., Pezdič, J. \& J. Head, 1989: Carbon uptake in aquatic plants deduced from their natural $\delta^{13} \mathrm{C}$ and ${ }^{14} \mathrm{C}$ content.- Radiocarbon, 31, 785-794.

McCrea, J.M., 1950: On the stable isotopic chemistry of carbonates and a paleotemperature scale.- Journal of Chemical Physics, 18, 849-857.

McGeehin, J., Burr, G.S., Hodgins, G., Bennett, S.J., Robbins, J.A., Morehead, N. \& H. Markewich, 2004: Stepped-combustion ${ }^{14} \mathrm{C}$ dating of bomb carbon in lake sediment.- Radiocarbon, 46, 893-900.
Meyers, P.A., 1994: Preservation of elemental and isotopic source identification of sedimentary organic matter.- Chemical Geology, 114, 289-302.

Meyers, P.A., 2003: Applications of organic geochemistry to paleolimological reconstructions: a summary of examples from the Laureatian Grate Lakes.- Organic Geochemistry, 34, 261-289.

Mook, W.G. \& J. van der Plicht, 1999: Reporting of ${ }^{14} \mathrm{C}$ activities and concentrations.- Radiocarbon, 41, 227-239.

Petrik, M., 1958: Prinosi hidrologiji Plitvica (Contributions to the Hydrology of the Lakes of Plitvice, Beiträge zur Hydrologie der Plitvicer Seen).- (English and German Abstract). In: J. Šafar (ed.) Nacionalni park Plitvička jezera. pp. 49-173, Zagreb.

Pichlmayer, F., Schoner, W., Seibert, P., Stichler, W. \& D. Wagenbach, 1998: Stable isotope analysis for characterization of pollutants at high elevation Alpine sites.- Atmospheric Environment, 32, 4075-4085.

Rodin, L.E. \& N.I. Bazilevich, 1967: Production and Mineral Cycling in Terrestrial Vegetation.- Oliver \& Boyd, pp. 288, Edinburgh, London.

Sah, S.P. \& R. Brumme, 2003: Natural ${ }^{15} \mathrm{~N}$ abundance in two nitrogen saturated forest ecosystem at Solling, Germany.- Journal of Forest Sciences, 49, 515-522.

Schelske, C.L. \& D.A. Hodell, 1995: Using of bulk sedimentary organic matter to reconstruct the history of nutrient loading and eutrophication in Lake Erie.- Limnology and Oceanography, 40, 918-929.

Srdoč, D., Krajcar Bronić, I., Horvatinčić, N. \& B. Obelić, 1986a: The increase of ${ }^{14} \mathrm{C}$ activity of dissolved inorganic carbon along the river course.- Radiocarbon, 28, 515-521.

Srdoč, D., Obelić, B., Horvatinčić, N., Krajcar Bronić, I., Marčenko, E., Merkt, S., Wong, H. \& A. Sliepčević, 1986b: Radiocarbon dating of lake sediments from two karstic lakes in Yugoslavia.- Radiocarbon, 28, 495-502.

Srdoč, D., Horvatinčić, N., Ahel, M., Giger, W., Schaffner, C., Krajcar Bronić, I., Petricioli, D., Pezdič, J., Marčenko, E. \& A. Plenković, 1992: Anthropogenic influence on the ${ }^{14} \mathrm{C}$ activity of recent lake sediment: A case study.- Radiocarbon, 34, 585-592.

Talbot, M.R., 1990: A review of the paleohydrological interpretation of carbon and oxygen isotopic ratios in primary lacustrine carbonates.- Chemical Geology, 80, 261-279.

Talbot, M.R. \& M. Laerdal, 2000: The late Pleistocene Holocene paleolimnology of Lake Victoria, East Africa, based upon elemental and isotopic analyses of sedimentary organic matter.- Journal of Paleolimnology, 23, 141-164. 
Talbot, M.R., 2001: Nitrogen isotopes in paleolimnology.- In: Last, W.M. \& J.P. Smol (eds.) Tracking Environmental Changes Using Lake Sediments - Physical and Chemical Techniques, Kluwer, pp. 401-439, Dordrecht.

Teranes, J.L. \& S.M. Bernasconi, 2000: The record of nitrate utilization and productivity limitation provided by $\delta^{15} \mathrm{~N}$ values in lake organic matter - A study of sediment trap and core sediments from Baldeggersee, Switzerland.- Limnology and Oceanography, $45,801-813$.
Verburg, P., 2007: The need to correct for the Suess effect in the application of $\delta^{13} \mathrm{C}$ in sediment of autotrophic Lake Tanganyika, as a productivity proxy in the Anthropocene.- Journal of Paleolimnology, 37, 591-602.

Vreča, P. \& G. Muri, 2006: Changes in accumulation of organic matter and stable carbon and nitrogen isotopes in sediments of two Slovenian mountain lakes (Lake Ledvica and Lake Planina) induced by eutrophication changes.- Limnology and Oceanography, 51, $781-790$. 